\title{
Reading Chaucer in New College, Oxford, in the 1630s: The Commendatory Verses to Francis Kynaston's Amorum Troili et Creseidae
}

The Latin translation of Chaucer's Troilus and Criseyde by Sir Francis Kynaston or Kinaston, published in part in 1635 as Amorum Troili et Creseida libri duo priores Anglico-Latini ('The two first books of the Loves of Troilus and Criseyde, in English and Latin'), has long been acknowledged as a particularly sensitive and detailed example of the seventeenth century's scholarly engagement with Middle English poetry. ${ }^{1}$ Kynaston's work was published not in London, as we might expect, but in Oxford, by the printer to the university, John Lichfield, and the fifteen commendatory poems that appear in the volume offer a multitude of perspectives not only on Kynaston's project, but also on Chaucer and his writings. Among the authors of these prefatory verses there is a peculiar dominance of fellows of New College, and the detailed knowledge of Chaucer's works that they reveal gives a suggestive insight into how groups of Oxford scholars engaged with Kynaston's activities as a translator through their own reading of Chaucer. In this article we investigate these commendatory verses, a narrow but rich seam of evidence for a variety of attitudes to Chaucer in the seventeenth century that occupy an unusual position in the history of Chaucer's reception. ${ }^{2}$ Taken as a whole, we argue, the poems suggest a peculiar concentration of Chaucerian enthusiasm in New College, Oxford in the period.

\section{$\underline{\text { Kynaston's Amorum Troili and its commendatory verses }}$}

The very fact that Kynaston (1586/7-1642) should choose to publish the first two books of his Latin Troilus and Criseyde in Oxford suggests, already, a scholarly venture; the local press seldom undertook anything that was not prompted by, or at least vendible to, the local academics and students. That the Latin translation and Middle English original are presented in parallel, and with explanatory glosses,

\footnotetext{
${ }^{1}$ The translation was first noted and described in modern scholarship by C. F. E. Spurgeon, Five Hundred Years of Chaucer Criticism and Allusion, 5 vols (Cambridge, 1914-1925) I, 206-15, who prints all but one of the commendatory poems, omitting that by Maurice Berkely. The understanding of the place of Kynaston's translation in the history of the reception of Chaucer has been greatly elucidated by Richard Beadle, 'A Virtuoso's Troilus', in Chaucer Traditions: Studies in Honour of Derek Brewer, ed. Ruth Morse and B.A. Windeatt (Cambridge: Cambridge University Press, 1990), pp. 213-33. See also Tim William Machan, 'Kynaston's Troilus, Textual Criticism and the Renaissance Reading of Chaucer', Exemplaria 5 (1993), 161-84. Kynaston's translation has been edited in recent years: see Helmut Wolf's admirable Sir Francis Kynastons Übersetzung von Chaucers 'Troilus and Criseyde' (Frankfurt am Main: Peter Lang, 1997 [Bibliotheca Humanistica, vol. 6]). Wolf's edition, a composite of the printed and manuscript witnesses, reproduces only four of the commendatory poems. See also Dana Sutton's 1999 edition of Kynaston's translation in his electronic Philological Museum: http://www.philological.bham.ac.uk/troilus/. Kynaston's notes and annotations to his translation of the Troilus have been edited by Judith May Newton, Chaucer's 'Troilus': Sir Francis Kynaston's Latin Translation, with a Critical Edition of his English Comments and Latin Annotations (unpub. Ph.D. diss., University of Illinois, 1967).

${ }^{2}$ New studies continue to build on Spurgeon's magisterial collection of Renaissance materials to illuminate the many different environments in which Chaucer's writings were consumed in the early modern period. An exemplary study in this regard is Alison Wiggins, 'What Did Renaissance Readers Write in Their Printed Copies of Chaucer?', The Library, $7^{\text {th }}$ ser., 9 (2008), 4-36. See also Seth Lerer's suggestive comments on the learned annotations in a printed copy of Stowe's Works, 'Latin Annotations in a Copy of Stowe's Chaucer and the Seventeenth-Century Reception of Troilus and Criseyde', Review of English Studies, n.s., 53 (2002), 1-7.
} 
furthers the impression that this was what we might think of as an academic edition. Kynaston himself had studied at Oriel College, Oxford, before moving to London from 1605 to take up residence in Lincoln's Inn. ${ }^{3}$ After being called to the bar 1611, he remained in London, balancing his eclectic intellectual interests with the pursuit of a more public life. He entered the service of the court and was knighted by James I in $1618,{ }^{4}$ and his achievements included, in 1635, the founding of the Musceum Minerva, an academy for young noblemen. Kynaston seems to have valued his own self-image as scholar and courtier, and indeed he projects this image onto Chaucer, going to great lengths to prove that Chaucer had been an intimate of the king and an esquire of the body. ${ }^{5}$ Although there is relatively sparse biographical evidence for Kynaston's continuing relationship with his alma mater after his departure for London, the very fact that Kynaston arranged for the publication of his Amorum Troili in Oxford helps demonstrate some continuing connection to the University and its scholars.

As promised in the preface printed alongside the Amorum Troili, Kynaston went on to complete a five-book translation of Chaucer's poem, which, although never published, survives in a single manuscript with Kynaston's Latin translation of Robert Henryson's Testament of Cresseid. ${ }^{6}$ Throughout, this manuscript is replete with copious notes and glosses, a beguiling combination of history, natural philosophy, and personal anecdote. John Urry drew upon it for his posthumous 1721 edition of Chaucer, and Kynaston's achievement in his translation of Troilus has been masterfully elucidated more recently by Richard Beadle, who rightly rehabilitates Kynaston as a major figure in the history of English editing. ${ }^{7}$ But as well as delving with almost philological detail into Chaucer's Middle English to create the base-text of his translation, Kynaston also trims the later books, somewhat flattening the presentation of Criseyde, and eliminating the poem's final reference to the Virgin Mary. This last shift may be another example of the typical post-Reformation tendency to present Chaucer as proto-Protestant in his affinities. Speght claimed, for example, that Chaucer was at Merton college with Wycliffe, 'whose opinions in religion he much affected'; and editors from the mid sixteenth century included the

\footnotetext{
${ }^{3}$ As Beadle points out ('The Virtuoso's Troilus,' p. 230 n. 9), by far the fullest biography of Kynaston is the unpublished study by H. G. Seccombe, The Life and Works of Sir Francis Kynaston (unpub. B.Litt. thesis, Oxford, 1933). Beadle gives an economical summary of Kynaston's life, 'Virtuoso's Troilus', pp. 214-9; for other accounts, see Anthony à Wood, Athena Oxonienses/Fasti Oxonienses, ed. Philip Bliss, 4 vols (London: Rivington et al., 1813), vol. 3, cols. 38-9; G. H. Turnbull, 'Samuel Hartlib's Connection with Sir Francis Kynaston's "Musaeum Minervae", Notes \& Queries 197 (1952), 33-7; ODNB. Note, after Beadle, 'Virtuoso's Troilus', p. 230 n. 10, that Kynaston did not temporarily move from London to Cambridge in the first decade of the seventeenth century; this error remains in the $O D N B$ entry.

${ }^{4}$ Seccombe, Life and Works, p. 16b.

${ }^{5}$ See Seccombe, Life and Works, pp. 31-2; also Beadle, 'Virtuoso's Troilus', p. 227.

${ }^{6}$ Oxford, Bodleian Library, MS Add. C 287. This manuscript has been most fully described by the two major editors of Robert Henryson: G. Gregory Smith (1906-14), and Denton Fox (1968). Note that Kynaston did not believe, as Speght's edition strongly implies, that the Testament of Cresseid was in fact by Chaucer (MS Add. C 287, pp. 475-6). Seccombe suggests that Kynaston's knowledge of the life of Henryson came to him through his acquaintance with the royal librarian Patrick Young (see below). ${ }^{7}$ Beadle, 'A Virtuoso's Troilus'. For a general account of the history of the editing of Middle English texts, see A. S. G. Edwards, 'Observations on the History of Middle English Editing', in Derek Pearsall (ed.), Manuscripts and Texts: Editorial Problems in Later Middle English Literature (Cambridge, 1987), 34-48. Kynaston's translation itself has received a reasonable amount of commentary, e.g. J. W. Binns, Intellectual Culture in Elizabethan and Jacobean England: The Latin Writings of the Age (Leeds, 1990), pp. 253-57.
} 
apocryphal Plowman's Tale, a piece of Wycliffite polemic, in their editions of the collected works. ${ }^{8}$ Throughout, Kynaston's translation is remarkable not least for its formal properties, matching Chaucer's rhyme royal stanzas with stanzas of rhymed Latin verse. Kynaston would reconvert this form into English in his last work, the rhyme-royal romance Leoline and Sydanus (London, 1642, repr. 1646), set, perhaps significantly, in ancient Britain. ${ }^{9}$ This fascination with England's medieval past is revealed elsewhere in Kynaston's writings, notably in his manuscript history of the English parliament, in which he sought to limit the antiquity and quash the power of parliaments, and affirm crown prerogative. ${ }^{10}$

The dedicatee of book one of the published version of Kynaston's Amorum Troili was Patrick Young, the Royal Librarian, one of the prominent Scottish scholarly family of that name. Kynaston also placed a second dedication before book two, addressed this time to John Rouse, Bodley’s Librarian; Rouse had been Kynaston's tutor at Oriel. But it is the address to Young that opens the volume, followed by Kynaston's short preface, before, at last, the commendatory poems themselves. These commendatory verses, like the dedications to the two most prominent librarians of the age, again further the sense that this edition was an avowedly academic endeavour. ${ }^{11}$ There are poems by Arthur Johnston, the great Scottish Neo-Latin poet-physician, who served as a royal physician, and who Kynaston had already translated; ${ }^{12}$ by William Strode, the university's public orator and himself a literary figure of some reputation in Caroline England; and by several other Oxonians of various colleges, including St John's, All Souls, and Christ Church. There is a contribution from Samuel Kinaston, Dean of All Souls, although it is uncertain whether this Kinaston had any family connection to the translator. ${ }^{13}$ But no

\footnotetext{
${ }^{8}$ For the reference to Wycliffe see Chaucer, ed. Speght, Works (London, 1602), sg. b3 r. For more details on Chaucer as a 'forerunner and sharer' of the opinions of the Reformers, see Spurgeon, Five Hundred Years of Chaucer Criticism and Allusion, Introduction, xix-xx. Speght's edition is discussed by Derek Pearsall, 'Thomas Speght', in Editing Chaucer: The Great Tradition, ed. Paul Ruggiers (Norman, OK, 1984), pp. 71-92.

${ }^{9}$ As Spurgeon notes, Leoline and Syndanus includes a passing reference to Troilus and Criseyde; see Chaucer Criticism and Allusion, I, 222.

${ }^{10}$ See Kynaston's $O D N B$ entry for the 'True presentation of forepast parliaments', probably written 1629. Note that this work is not mentioned by Seccombe in Life and Works.

${ }^{11}$ See Falconer Madan, Oxford Books, Vol. I: The Early Oxford Press, 1468-1640 (Oxford: Clarendon Press, 1895), p. 183. Wood commented: 'Which being beheld as an excellent translation, was usher'd into the world by 15 copies of verses made by Oxford men, among whom are W. Strode the orator, Dudley Digges and Sam. Kinaston of All-s coll. Tho. Gawen of New coll. Maur. Berkley, Will. Cartwright, both of Ch.Ch. \&c.' For an index of such verse, see Franklin B. Williams, Index of Dedications and Commendatory Verses in English Books Before 1641 (London: The Bibliographical Society, 1962). The collation of the book shows how signatures bearing the commendatory verse $\left(\dagger^{4}\right.$, $* 4, * * 2$ ) were inserted late, for $\mathrm{sg}$. A4v originally bore the first page of the Latin text of the poem (paginated as p. 2), which in the event had to be torn off and remounted after sg. $* * 2$, in order to face once more the first page of the English text of the poem (paginated as p. 3). This arrangement is confirmed by the occasional uncorrected copy, where the first page of the Latin text is separated from its facing English page by the intervening poems, e.g. the copy in the National Library of Scotland, Dav.II.5.35. That the poems of Reade and Evans, discussed below, are both in the last, half-gathering of commendatory verse, may suggest that they were collected late in the process of publication.

${ }^{12}$ Kynaston's two translations immediately prior to his Chaucer had been the Musce querulce: de regis in Scotiam profectione (1633), Latin poems on the king's journey to his Scottish coronation with English renditions by Kynaston on facing pages; and then the Musce aulica autore Ionstono (1635), another parallel text of the Latin panegyrics of Arthur Johnston, with Kynaston's translations.

${ }^{13}$ Foster, Alumni Oxonienses 1500-1716 (Oxford, 1891), states that Samuel Kinaston was from Salisbury and matriculated at Lincoln College on 9 November 1621, aged 16. He took his BA in 1625
} 
fewer than a third of all the poems, and the majority of those in English, came from five fellows of New College: Thomas Gawen, ${ }^{14}$ William Barker, ${ }^{15}$ Samuel Evans, ${ }^{16}$ Thomas Reade, ${ }^{17}$ and Francis James. ${ }^{18}$ What these men had to do with Kynaston remains obscure; it may simply be that Kynaston, although a London resident, had a personal connection with one of them, and through this means several other New College versifiers were asked, or sought out an opportunity, to contribute to this venture. There is a tantalising suggestion, which we have been unable to verify, of a

and his MA (from All Souls) 1628, and incorporated at Cambridge in 1634. He became successively rector of Blackmanston, Kent, in 1630, and of Somerford Magna, Wiltshire, in 1637. For his duties as Dean of All Souls, see Scott Mandelbrote and John Davis, eds., The Warden's Punishment Book of All Souls College, Oxford, 1601-1850= Oxford Historical Society, n.s., no. 45 (Oxford, 2013), pp. 69-72. 14 Thomas Gawen, from Gloucester, son of a clergyman, matriculated 28 June, 1633, aged 23, taking his BA 18 April, 1634, and his MA 5 July, 1639. He became chaplain to Walter Curl, Bishop of Winchester, and was a prebendary at Winchester from 1645, as well as rector of Exton, Hants, 1641, and rector of Bishops Stoke, Hants, 1643, until sequestered in 1645 for his delinquency against the Parliament. He travelled widely on the continent as a tutor, and turned Roman Catholic. Interestingly, Wood claims that Gawen while travelling in Italy 'accidentally sometimes fell into the company of John Milton the antimonarchist'. He died in Pall Mall 8 March 1683, his A Brief Explanation of the Several Mysteries of the Holy Mass (London, 1686) appearing posthumously; Wood also lists several unpublished works and translations, including some poetry (Wood, Athence Oxonienses, vol. 4, cols. 130-31, and see also Foster). He contributed a Latin poem to a 1631 Oxford collection presented to Johann Cirenberg of Danzig: it is probably not be a coincidence that this short volume was edited by John Rouse, and other contributors included Thomas Master of New College, as well as William Strode and William Cartwright, both contributors to Kynaston's Chaucer. See John Rouse, ed., Ad magnificum et spectatissimum virum Dominum Iohannem Cirenbergium Proconsulem civitatis Gedanensis (Oxford, 1631). This publication was to thank Cirenberg for presenting, via Sir Thomas Roe, what became Bodleian, MS Roe 20, a fifteenth-century Latin Epistolae synodales Synodi Basilensis (Madan, Oxford Books, I, p. 16; Summary Catalogue). For a handful of his other works, see below, p. 12.

${ }^{15}$ Foster states that he was of Great Horwood, Bucks, matriculated as a gentleman on 15 February 1622, aged 19; his degrees were BA, 22 November 1625; MA 6 June 1629; BD 25 May 1637; and DD 5 September 1661. He was a fellow from 1621, and was expelled by the Parliamentary visitors in 1648. Upon the Restoration he became canon of Canterbury in 1660, rector of Hardwick, Bucks, in 1661, and died there 26 March 1669. Two additional poems by Barker are mentioned below, p. 12 .

${ }^{16}$ Foster (and see Venn \& Venn, Alumni Cantabrigienses) states that he was from Bierton, Bucks, where his father was the vicar. He matriculated on 11 March 1625, aged 18; was awarded the BCL on 11 October 1632, and incorporated LLB at Cambridge in 1635. He became rector of Syresham, Northamptonshire in 1637. Access to Archives lists two documents concerning Evans at Syresham, one of which shows that he was still the incumbent in 1655 (Warwickshire County Record Office, CR 2981/Dining Room/Cabinet/Drawer 6/36). Evans also furnished a commendatory poem for Charles Butler's Principles of Musik (London, 1636), to which John Pinck of New College also contributed. Evans's Latin poem shows his appreciation of Butler's earlier work on bees, The Feminine Monarchie, or a Treatise Concerning Bees (1609). The third edition (1634) of that work was printed in Butler's phonetic spelling; here Pinck, rather in the spirit of Francis James's Chaucerianism discussed below, employed Butler's proposed orthography for his own contribution, in English.

${ }^{17}$ Foster states that he matriculated as a gentleman from Linkinholt, Hants, on 11 October 1631, was awarded the BCL on the same day and his DCL on 8 May, 1638, and was appointed advocate of Doctors' Commons in 1661 . Wood provides an entry on him, stating that he was 'a most noted royalist, trailed a pike for his majesty in the university of Oxford', and was nominated by Charles I as Principal of Magdalen Hall in 1643. He became a Roman Catholic and went abroad; but after the Restoration he returned, becoming a surrogate for Sir William Merick, judge of the prerogative court. He died in 1669. Wood had heard that he was the author of An Answer to a Book Entituled, An Account of the Church Catholike (Paris, 1654), being a reply to Edward Boughen's work of that title (London, 1653) (Wood, Athence Oxonienses, vol. 3, cols. 390, 831-32). A handful of other poems by Reade is mentioned below, p. 12.

${ }^{18}$ For James's biography, see below. 
personal relationship between Kynaston and Francis James; James's contribution is looked at in detail below. ${ }^{19}$ As we shall see, several of these New College poems, particularly James's, engage with both Kynaston's project and Chaucer's writings with particular depth. It is certainly possible to imagine an affinity between Kynaston and these men; we have already mentioned Kynaston's monarchist credentials, and Gawen, Barker, and Reade all lost their fellowships for their royalism in the civil war period; Reade was apparently in arms for the king in the occupation of Oxford; and both Gawen and Reade eventually turned Roman Catholic.

If Kynaston's connection to these New Collegians is somewhat obscure, it is equally uncertain why New College in particular should foster a cluster of scholars who seem to take an unusually close interest in Chaucer and in Kynaston's translation. The New College library holds the 1602 Speght edition of Chaucer; this was probably in the library not long after publication, and bears some slight marks of reading, such as the underlining of sententice, and the annotation of some entries in the glossary. Lending records for college library only survive from 1665, but it was borrowed that very year. ${ }^{20}$ The college also acquired a manuscript copy of Chaucer (MS 314), although this book only arrived in the college in around 1686, the gift of the London 'bibliopola' or stationer Charles Tooker, who appears to have been an auctioneer. ${ }^{21}$ Alongside the Chaucer materials, there is a smattering of evidence for an interest in the works of Gower and Lydgate in New College in the early modern period. ${ }^{22}$ It may be relevant that in the year after the publication of Kynaston's translation, New College was paid a visit by the impecunious Bohemian exile Václav Klement, or 'Venceslaus Clemens a Lybeo-Monte', as he called himself in Latin. His writings included the Trinobantias, an encomium on London in Latin hexameter, with

\footnotetext{
${ }^{19}$ Seccombe notes that Kynaston mentions one Francis James in the notes to his manuscript version of the Amorum Troili, although Seccombe confuses the Francis James who contributes a poem with his older cousin, Francis James the Latin poet. Seccombe, Life and Works p.11 n. 4. Seccombe does not give a page reference for this supposed reference, and we have been unable to locate it.

${ }^{20}$ The 1602 edition is BT1.19.2, lacking the title-page. The surviving lending register is edited in William Poole, 'Book Economy in New College, Oxford, in the Later Seventeenth Century', History of Universities 25 (2010), pp. 56-137.

${ }^{21}$ Benefactors Book, p. 131; for Tooker see Giles Mandelbrote, 'The Organization of Book Auctions in Late Seventeenth Century London', in Under the Hammer: Book Auctions since the Seventeenth Century London, eds. Robin Myers and Michael Harris (London, 2001), pp. 15-50, at pp. 18-20, 22, 24-5. Tooker, who 'fits into a somewhat shadowy group of individuals who made their living from their knowledge about books, as intermediaries in the world of secondhand and antiquarian bookselling', was at around this time probably involved in the sale of the important libraries of the astronomer Sir Jonas Moore (in 1684) and the oriental scholar Edmund Castell (in 1686). Tooker's connection with the college is obscure, but it may be significant that he came from Winchester (McKenzie and Bell, A Chronology and Calendar of Documents Relating to the London Book Trade 1641-1700, II. 967).

${ }^{22}$ The college acquired its illuminated MS of Gower (MS 266) from the civilian Thomas Martin in 1588. The college's copy of the 1554 printed edition of Gower, according to the inscription on the copy itself, was donated by Edward Evans, probably in c. 1614-16 (BT1.131.18; see the Benefactors Book, p. 50, for books given by Evans at that time, but not listing this volume); and a personal copy of the 1554 edition was also listed among the chattels of a young artista who died in the college in 1652 (Poole, 'Book Economy', p. 91). For Lydgate, the glancing evidence is an allusion in the academic play Fallacy (c. 1615), almost certainly written by Richard Zouche of New College. An allusion there to 'Death's dance in Bocace; Popes, Dukes, Earles, Lords, Knights, Marchaunts, Victuallers, Vintners' (British Library, MS Harley 6869, fol. 26r), is surely to the illustration in John Lydgate, A Treatise ... Shewing ... in Maner of Tragedye, the Falles of Sondry ... Princes and Princesses [with] The Daunce of Machabree (London: Richard Tottel, 1554), suggesting that the implied audience of that play knew the book well.
} 
digressions on Oxford and Cambridge, a work that heaps particular praise upon Geoffrey Chaucer. Clemens's knowledge of Chaucer is derived entirely from his reading of Kynaston's Latin translation. ${ }^{23}$ So while these New College fellows may well have read their Chaucer in New College library, there are only suggestive hints of a particular interest in Chaucer or Middle English writings more generally in the college in the period. What is remarkable, however, is the detail with which these poems engage with Chaucer's writings, and this detail can only be appreciated when viewed alongside the other commendatory poems in the collection, and the perspectives that they afford on Kynaston's interaction with Troilus and Criseyde.

One striking aspect of Kynaston's literary project was the respect he granted to the integrity of Chaucer's Middle English: his Latin verses were intended to open up, rather than supplant, Chaucer's text. As an editor-translator his attitude was essentially conservative, and in his preface he explicitly distances himself from those sixteenth-century French bookmakers who had modernised the language of the great work of medieval francophone literary culture, the Romance of the Rose. ${ }^{24}$ Chaucer had shown himself to be alert to the problem of language change at the beginning of Book II of Troilus and Criseyde, and Kynaston's translation of these lines brings into focus the Middle English poet's uncanny foresight of his own linguistic obsolescence:

I know that in forme of speech is chaunge

Within a thousand yeere

Loquendi forma, scio, quòd mutata

Sit intra seculum ... 25

Kynaston seems, indeed, consciously to play with the relationship between the language of his own translation and his Middle English source. As Tim William Machan has pointed out, he transforms Chaucer's claim to be translating from a Latin source - 'But out of Latin, in my tongue it write' (II.14) - into a comment on his own work's position in relation to the English vernacular: 'E nostro in Latium sed verterim

\footnotetext{
${ }^{23}$ For the unfortunate Clemens, see William Poole, 'Down and Out in Leiden and London: The Later Careers of Venceslaus Clemens (1589-1637), and Jan Sictor (1593-1652), Bohemian Exiles and Failing Poets', The Seventeenth Century 28 (2013), pp. 163-85. Clemens donated a number of his own books to New College when he visited. The Benefactors Book (New College, BT 1.4.6 = NCA 3582) lists his donation under 1639, but that cannot be right as Clemens was dead by then; the likely date of presentation is bounded by the most recently published book he presented (1636), and his death the following year.

24 'Nec enim sine exemplari erassem, si hoc prostitissem, cum Poema quoddam Gallicum, cui titulus Legenda Rosea, à quodam Gulielmo de Lorris trecentis fere ab hinc annis inchoatum, \& post quadraginta annos opera Iohannis de Mohun absolutum, septies ex eo tempore gallice editum, et phrasi uniuscuiusque seculi apatum, et quasi de novo scriptum fuerit' (sg. †1v) ['And indeed I would not have been erring without example if I had done this, because a certain French poem, entitled the Romance of the Rose, written three hundred years ago by a certain Guillaume de Lorris, and completed by the work of Jean de Meun forty years later, has been edited seven times in French since that time, and adapted to the phrasing of the age and rewritten as if new']. Kynaston is presumably thinking of the 1526 version of the Romance of the Rose attributed to Clément Marot, which modernised spelling, syntax, and word-order, and amended the meter (but generally left the lexis unchanged). See Stephen G. Nichols, 'Marot, Villon, and the Roman de la Rose: A Study in the Language of Creation and ReCreation', Studies in Philology 64 (1967), 25-43.

${ }^{25}$ Amorum Troili, sg. Q2r.
} 
sermone' ${ }^{26}$ The intellectual issues at stake in this act of placing Middle English alongside parallel Latin verse are already present in the fabric of his translation.

The commendatory verses prefaced to Kynaston's translation respond to these issues with varying levels of detail and skill. Was Chaucer to be seen as a 'backwards' medieval poet, rough and rude, the relic of an uncivilized age? Could his poetry be rescued by translation into some more current tongue? Or was there an art to this medieval writer that might require explanation, but not emendation or revision? The verses collected in Kynaston's book focus for the most part on how Kynaston has opened up Chaucer's text for new generations and new nations. As William Cartwright rather imperialistically puts it, also commenting on Kynaston's unique Latin versification in imitation of Chaucer's rhyme royal stanzas:

Rome in her Language here beginnes to know

Laws yet vntry'd, proud to be fetterd so;

And, taught our Numbers now at last, is thus

Growne Brittaine yet, and owes one change to vs. ${ }^{27}$

Some of the poems seem spectacularly to miss the point of Kynaston's conservative and inherently respectful attitude to Chaucer's Middle English, by suggesting that the Neo-Latin translation has supplanted the medieval work, or, as Edward Foulis has it in his English poem, 'Thus the Translation will become / Th'Originall [...] None / Sees Chaucer but in Kinaston'. The group of five New College poets address similar issues of language change, continuity, geographical expansion, and versification, yet for the most part with a particular sensitivity to Kynaston's fundamentally conservative attitude to Chaucer's language. Yet this New College group is not homogenous: while Gawen's vague obsequiousness seems to err in promoting the translation over the original, Reade's poem demonstrates a greater sensitivity to Kynaston's approach, and the three remaining New College offerings, from Evans, Barker, and James, all present to differing degrees what looks to be a genuine engagement with Chaucer's writings. In this respect they are unique amongst the verses collected in Kynaston's volume, and may well be some of the most imaginative responses to medieval literature in the period.

Gawen, the first of the New College contributors, is eager to commend Kynaston; he sees Kynaston as playing Virgil to Chaucer's Homer, or Terence to Chaucer's Naevius:

Sic in Virgilio legas Homerum,

Sed præ Virgilium eligas Homero:

Est in Carmine Noevius Terenti,

Sed carmen melius Terentianum ...

[Thus one reads Homer within Virgil, but prefers Virgil to Homer; and Naevius is within Terence's poetry, but Terence's poetry is better.]

Like most of the writers of these commendatory verses, Gawen's vague praise of Kynaston for showing the 'Chaucerum Ingenij redintegrati' ('the genius of Chaucer

\footnotetext{
${ }^{26}$ Amorum Troili, sg. Q1r . On this, see Machan, 'Kynaston's Troilus', p.181.

${ }^{27}$ On Kynaston's Latin prosody, see Ryan, 'Chaucer's Criseyde in Neo-Latin Dress.'
} 
renewed') does not demonstrate particular interest in, or indeed knowledge of, the works of Chaucer himself.

Reade's poem, meanwhile, without betraying any suggestion of a profound engagement with Chaucer's writing, does seem to have a particular sensitivity towards Kynaston's project. He makes implicit reference to the prosody of Kynaston's rhyming Latin, but above all Reade recognises that Kynaston has produced more than a simple translation - he has also made a 'comment', a way of understanding Chaucer's original Middle English:

Thou [i.e., Chaucer] hast a friend, that while

He studies to translate, his Latine stile

Hath Englisht thee, and cunningly in one

Fram'd both a comment and Translation.

Reade insists that any 'rudenesse' in Chaucer's verse is only 'seeming', and that a failure to understand his writings points to a deficiency in the reader, not the author:

Nor wert thou old, but in thy outward hew;

Thy judgement and invention yet are new.

Thy seeming rudenesse might some ballad-poet

That skill'd thee not, amaze, whereas we know it.

The best adore thee, from which learned sect

Thou differ'st not in worth, but Dialect.

The three remaining New College poems, alone amongst the commendatory verses for Kynaston, make direct or implicit reference to Chaucer's works beyond Troilus and Criseyde. William Barker supplied two poems, one in Latin and then a longer one in English, both under the general title 'In Translationem Authoris' ('On the Translation of the Author'). Barker's Latin poem is notable because he too has attempted the quasi-medievalism of treating Latin as accentual, and he too rhymes his Latin lines, although in couplets rather than stanzas. His concludes his little poem by imagining himself as another Troilus: Criseyde is so fine a mixture of love and inconstancy, 'Vt ego, si iam viveret, amarem, / Fortassis etiam plusquam Basiarem' 'that were she now living I would love her, and perhaps more than that, kiss her too.' It is in Barker's sixteen English couplets, however, that he renders clear his attitude to Kynaston's scholarly activities. He opens by celebrating that Chaucer's 'strong food' is now once more thought digestible, 'That Learning's not absurd; and men dare know, / How Poets spake three hundred yeares agoe':

Like travellors, we had bin out so long, Our Natiue was become an vnknowne tongue, And homebred Chaucer vnto vs was such, As if he had bin written in High Dutch:

Till thou the Height didst Leuell, and didst Pierce

The depth of his vnimitable verse.

Let others praise thy how; I admire thy what.

Twas Noble, the adventure; to Translate

A booke, not tractable to every hand, And such as few presum'd to vnderstand:

Those vpstart verse-wrights, that first steale his wit, 
And then pronounce him Dull: or those that sit In judgement of the Language they nere view'd, And because they are lazie, Chaucer's Rude.

Like Reade, Barker insists that Chaucer's 'rudeness' was more a result of critical ignorance than a genuine failure on Chaucer's side, and this reminds us of the debates at the time concerning in particular Chaucer's prosody. What is most interesting about Barker's poem, however, is the striking Chaucerian allusion with which it closes. In the final lines of his contribution, Barker imagines a revivified Chaucer in the court of King Charles; the King's 'Rayes' of virtue dart into the poets of his court, who shall make his royal deeds 'The Subject of a Second AEneids'. Barker encourages Chaucer to look out for Kynaston, his translator, among the writers who surround Charles:

If there among those Swans thou Him shal see, That to our knowledge thus hath reseued thee. Then call thine Eagle down to raise his Name From Troilus vp to the Howse of Fame

As well as suggesting that the poets of his own age are mere 'Swans' in comparison to Chaucer's 'Eagle', the most noble of the birds, Barker is also alluding directly to the eagle who appears in Chaucer's House of Fame, who picks the narrator up in his talons and transports him through the heavens to the House of Fame in a sly parody of Dante's eagle in the Purgatorio and Virgil's description of the seizure of Ganymede. ${ }^{28}$ The House of Fame is a difficult and incomplete work: it is remarkable to find an easy, almost conversational allusion to it in the work of a seventeenthcentury reader. ${ }^{29}$

The final two commendatory poems to Kynaston's book merit a much closer examination. The poem contributed by Samuel Evans is striking, above all, in its irreverently ludic approach. Using the popular idea that Britain was founded by Brutus, a descendant of the Trojan royal family, as a means of linking Troilus and Criseyde with the Canterbury Tales, Evans hopes that Troilus might be joined by some of Chaucer's less exalted characters, 'True Troians all', in being translated by Kynaston into Latin verse:

First let the Troian Boy arise, and then

True Troians all, they are his Countrymen.

The Sumner, Franklin, oh that I might heare

The Manciple, and early Chaunticleare

Crowe latin, next might see the Reue, and Logge, ${ }^{30}$

\footnotetext{
${ }^{28}$ See Chaucer, House of Fame, 496-1088, in The Riverside Chaucer, ed. Larry D. Benson (Oxford, 1987). All subsequent references to Chaucer's works are to this edition. For Dante's eagle, see Purgatorio, IX.19-45, in The Divine Comedy, ed. and trans. Charles Singleton (Princeton, 1973); see also Aeneid, 5.253-60.

${ }^{29}$ To a reader of Speght's edition, the House of Fame would not have seemed as strikingly unfinished as it was presented in medieval manuscripts and as is seen now in modern editions. In his edition, Speght follows Thynne in incorporating Caxton's invented twelve-line conclusion to the poem. Although Caxton identified this interpolation as his own work, Thynne, like Speght, suppresses this suggestion. See House of Fame 2157t.n., in Riverside Chaucer.

${ }^{30}$ We can find no clear explanation for this word, 'Logge'. It is italicised like the proper names of the other pilgrims, the 'Reue' [Reeve] and the 'Manciple', and it is tempting to read this as a garbled or
} 
The Miller and learne Latine for a Cogge,

The Merchant, and Sir Topas height, the wife

Of Bathe, in vulgar Latine scold for life.

But aboue all the famous Legacie

Amongst the Conuent dealt, so Legally,

Where twelue divide the As, and every one

Hath part 'withouten Defalcation'

And all in Latine ...

Evans had clearly read his Chaucer: his engagement with the Canterbury Tales is close. Part of the irreverent humour of Evans's verse is the recognition that the Canterbury Tales is markedly different in style and tone to the elevated and selfconsciously classical Troilus and Criseyde. Evans wryly looks forward to learning the 'Latine for a Cogge': the mundane realities and low diction of the Canterbury Tales would be difficult to articulate in formal Latin. ${ }^{31}$ More than simply naming Canterbury pilgrims, Evans shows his close acquaintance with the Summoner's Tale in particular. The 'famous Legacie' - Evans's reference to the fantastically crude denouement of the story - echoes the language of the brief plot-summary Speght places at the beginning of his edition of this tale: 'A begging Fryer comming to a Farmars house who lay sicke, obtaineth of him a certaine legacie, which must bee equally deuided among his Couent.' This legacie, of course, is not a financial bequest, but the farmer's petty revenge: he farts into the friar's hand, leading to a mockscholastic disputatio on how a fart can be divided amongst his brethren into twelve equal parts. ${ }^{32}$ Evans's euphemism for the fart - 'where twelve divide the As' - is a reference to the as, Roman bronze or copper coin subdivided into twelve parts, hammering home an emphasis that the Summoner's Tale is essentially about the pecuniousness of the friars. ${ }^{33}$ Since, as the $O E D$ points out, the usual equivalent in English translations of the Bible for the Roman as was 'farthing' it seems very likely

misprinted reference to Roger the Cook, 'Hogge of Ware' (CT, I 5336). But the reading 'Hodge' appears in the editions of the Works by Thynne (1532, sg. F2v), Stowe (1561, sg. D5r), and Speght (1598, sg. D5r, and 1602, sg. D5r), and since in Evans's couplet the word 'Logge' rhymes with 'Cogge', he would have had to quite radically misremember this single reference to the diminutive form of the Cook's first name. If 'Cogge' in the following line is understood to refer to the act of cheating at dice (see below, n.31), this might support the suggestion that Evans is thinking of the Cook and his tale. 'Logge' could be a reference to the Host: perhaps a form of the word lodger (as in 'one who lodges a person; a host'), abbreviated for the rhyme (for this old sense of the word, see $O E D$, s.v. lodger, (n. 2, obs); or perhaps a piece of urban or university slang for 'bar-man' or 'publican' (the $O E D$ records an obsolete sense of the word $\log$ which had some currency in the early seventeenth century: 'In Old St. Paul's, a block or bench on which serving-men sat' (OED, s.v., log, n.I.1.f)). For a different example of a similar sort of metonymy compare $O E D$, s.v., bench (n.1d), 'The judges or magistrates collectively, or the judge or magistrate sitting in the seat of justice.' If we assume that an abbreviation of lodger would be pronounced with a word-final / $\mathrm{d}_{3} /$, then $\log$ is a better match for the word-final $/ \mathrm{g} /$ of the rhyme-word, 'Cogge'.

31 'Cogge' might mean 'mill wheel', in reference to the Miller mentioned at the beginning of the line. But in early modern English cog can also refer to the act of 'cogging', or cheating at dice (OED, s.v., $\operatorname{cog}$ n.4, 1a). The word may thus be a reference to the Cook's Tale, with its depiction of urban lowlives and gamblers; note the heading that Speght gives this tale in his edition: 'The description of an vnthriftie Prentice, giuen to dice, women and wine'.

${ }^{32}$ Canterbury Tales, III 2140-9, 2216-86.

${ }^{33}$ See $O E D$, s.v. as (n.1). 
that Evans's 'As' constitutes a deft inter-lingual pun on 'farting' ${ }^{34}$ Evans also includes a flash of Middle English with the phrase 'withouten Defalcation'. Following the editorial practice for dealing with Middle English initiated by Speght, and followed in Kynaston's printing the original text of Troilus in parallel with his Latin, the phrase 'withouten Defalcation' is printed in 'black-letter' type to mark its supposedly archaic nature. ${ }^{35}$ Yet while withouten would no doubt have been recognised by Evans's readers as a genuinely Chaucerian word, defalcation appears only very late in Middle English, nowhere in Chaucer, and, as a word with some currency in the seventeenth century, would probably not have seemed particularly archaic. Since defalcation has a primarily financial meaning, Evans seems, as with his reference to the as, to be placing a particular emphasis on the friars' covetousness. It seems likely that Evans is again attempting a pun in this line, exploiting the closeness in sound of defalcation and defecation. If this is true, however, Evans is not quite implying the modern sense of defecation, 'the discharging of faeces', a sense which the $O E D$ first records only in the nineteenth-century. ${ }^{36}$ In early-modern English, defecation was used primarily in its etymological sense as 'the removal of faeces', with 'faeces' understood more widely as sediment, waste, dregs, and, of course, excrement. ${ }^{37}$ So if Evans's pun is there, his poem is suggesting on the literal level that the friars will receive their farthing without any diminution in its value, but with the underlying implication that they will receive their fart in all of its foulness, without having been cleansed of any impurities, including perhaps human excrement.

Understanding Evans's 'defalcation' as a pun in the same vein as his 'farthing' for 'farting', furthermore, helps explain why Evans might focus our attention on it by having it printed in black-letter, when it is not in fact an archaism. In the final lines of his poem these deft word-plays derived from the Summoner's Tale are subsumed into a more general anti-papal sentiment, as Evans suggests that Kynaston's hypothetical Latin translation of this work will allow 'the Pope [...] and all the sacred Troupe / Of Cardinalls' to learn about and adopt Chaucer's suggested technique for the equal partition of farts. This is, once again, the post-Reformation English Chaucer, whose general medieval anti-clericalism can be co-opted into a very modern anti-papalism.

For all four of the New College fellows looked at so far, it is perhaps possible to trace a network of affiliation through their shared contribution to verse collections published in Oxford in the 1630s and 1640s. Verses by Evans, Reade, and Gawen,

\footnotetext{
${ }^{34}$ See $O E D$, s.v., farthing (n.1). For farthing as translation of as, see the Authorized Version of Matthew 10.29: 'Are not two sparrows sold for a farthing?', translating 'nonne duo passeres asse veneunt'. The pun is nearly homophonous if Evans and his circle pronounced 'farthing' as farding, an attested e.Mod.Eng. pronunciation: see E. J. Dobson, English Pronunciation 1500-1700, 2nd ed. (Oxford, 1968), II, §383 and n.1. Dobson sees farding as 'the test case establishing the [rð] > [rd] change'.

${ }^{35}$ In representing (mock) Middle English in blackletter, the dedicatory poems echo the format of the parallel translation itself, and, indeed, the editorial practice of Speght, who sets his early-modern English comments in Roman type, and Chaucer's text in blackletter, and Latin in Italic. The conventional nature of these typographical choices - for instance even Marlowe's Dr Faustus in both its 1604 and 1616 quartos was printed in blackletter - problematises Machan's suggestion that Kynaston's setting of Chaucer in black-letter type represents a conflicted desire to 'distance' Chaucer culturally, while also modernising and universalising him through Latin. See 'Kynaston's Troilus', 176-7.

${ }^{36}$ See $O E D$, s.v., defecation (n.3).

${ }^{37}$ See $O E D$, defecate, from Latin defaecare < de + faeces. See also OED, s.v., faeces n.1 and n.2.
} 
appear in the Solis Britannici Perigceum (Oxford, 1633), ${ }^{38}$ while Evans, Reade, and Barker all contributed poems to the Flos Britannicus (Oxford, 1637). ${ }^{39}$ Evans also wrote for the Musarum Oxoniensium Charisteria (1638), and the Horti Carolini Rosa Altera (1640). ${ }^{40}$ Barker appears once again, alongside Reade, in the Musarum Oxoniensium Epibatêria (Oxford, 1643). ${ }^{41}$ But none of these verse collections include works by the fifth and the most interesting of the New Collegians to contribute a commendatory poem to Kynaston's Troilus.

\section{$\underline{\text { Francis James's 'Middle English' }}$}

The final New College poem, and the most immediately striking of all the commendatory verse, is that of Francis James (1607-?). ${ }^{42}$ This James was the son of Thomas James (1573-1629), in his time also a fellow of New College, famous in the annals of scholarship as Bodley's first librarian, and one of the most energetic bibliographers of his day. Among the early publications of Thomas were his edition of the Philobiblon of the early fourteenth-century bishop and bibliophile Richard de Bury (Oxford, 1598), and the Ecloga Oxonio-Cantabrigiensis (Oxford, 1600), a union catalogue of manuscripts in the Oxford and Cambridge college libraries, and in Cambridge University Library. In 1605 he published the first Bodleian catalogue. Although Thomas James's writings reveal an overwhelmingly theological rather than literary interest, it is significant that, in the frieze he designed for the Upper Reading Room of the Bodleian Library around 1616, 'Galfridus Chaucer' features as one of only two English poets, appearing alongside Ovid and not far from Petrarch, Dante and Boccaccio. ${ }^{43}$ Thomas James may therefore have taken more interest in the fourteenth-century poet than his surviving writings suggest. Thomas's nephew, another Francis James (d. 1621), was a noted Latin poet. ${ }^{44}$ A further nephew, cousin to the younger Francis James, was Richard James (1592-1638) the antiquary and poet, and a fellow of Corpus Christi College, Oxford. This James had some serious medieval interests. He wrote (but did not finish) a history of his native Isle of Wight under the Saxons and Normans, and he prepared a vigorously Protestant study of

\footnotetext{
${ }^{38}$ For Evans, see Solis Britannici Perigceum (Oxford, 1633), sgs. G3v-[G4]r. Reade appears at sg. G1r$\mathrm{v}$, while Gawen appears twice, at sgs. K1v-K2r, M2v-M3v.

${ }^{39}$ Flos Britannicus (Oxford, 1637), sg. [C3]v (Reade), [E3]v-[E4]r (Evans, Barker). Copies of this work vary in length and order, and the sheets are unsigned; we have referred to the Bodleian copy, shelfmark B 13.4 (3) Linc.

${ }^{40}$ Musarum Oxoniensium Charisteria (Oxford, 1638), sg. B3r (his poem on Henrietta Maria opens perhaps provocatively 'Ave Maria'); Horti Carolini Rosa Altera (Oxford, 1640), sgs. **2v-**3r

${ }^{41}$ Musarum Oxoniensium Epibatēria (Oxford, 1643), sg. A4r-v (Reade), sgs. ${ }^{2} \mathrm{~A} 2 \mathrm{v}-\mathrm{A} 3 \mathrm{r}$ (Barker).

42 James matriculated 19 October 1627, aged 19; he took his B.A. 21 April, 1631; and then his M.A. from New Inn Hall 20 January 1634-5. He was subsequently appointed rector of North Marden, Sussex, in 1639 (Foster). Dispossessed during the civil war, in the 1650s James was in Hayes, Middlesex, where Patrick Young, the royal librarian and dedicatee of Kynaston's translation, also dispossessed, was incumbent in 1648. From Hayes, in the 1650s, James launched a raid on Oxford to retrieve his father's books after the death of his mother, Ann, in 1655 (TNA PRO C7/434/32). His son, Thomas (baptised 1640) went on to become a printer in Mincing Lane, London. We are grateful to Professor Tom James for much help with Francis James's biography.

${ }^{43}$ Philip Sidney is the other English poet to appear in the frieze. See J. N. L. Myres, 'The Painted Frieze in the Picture Galery', Bodleian Library Record 3 (1950), 82-91, at p. 87. We are indebted to Professor Tom James for suggesting this connection. The image of Chaucer can still be seen on the south wall of the north side of the Upper Reading Room, and beside Chaucer's portrait is a book is depicted, with its title displayed on the spine: 'Canterbury Tales'.

${ }^{44}$ See Foster for this Francis James, matr. Christ Church, 1598.
} 
Thomas à Becket. He was famed as a linguist, having mastered, it was said, Old English, French, Gothic, Greek, Hebrew, Italian, Latin, and Russian; indeed, he prepared manuscript dictionaries of the first and last of these languages. Perhaps most importantly for our purposes, Richard James also had a recorded interest in Middle English poetry, producing a copy of Thomas Hoccleve's 'Address to Sir John Oldcastle' with a detailed commentary. Richard James used Hoccleve's diatribe against this Lollard Knight to excavate what he believed to be the early murmurings of English Protestantism, seeing Oldcastle as a 'man of valour and virtue, and only lost in his owne times bicause he would not bowe vnder the foule superstition of papistrie'. ${ }^{45}$ Our Francis James, by contrast, has left a much more modest record of his scholarly achievements. Nevertheless, he came from a family of scholars with unusually strong interests in England's medieval past, and indeed Middle English poetry; this background may have helped to inform his ingenious, linguistically explorative poem.

For James's poem demonstrates a remarkable familiarity with Chaucer's writings, and is arrestingly written in an imitation of Chaucerian English. As with Evans's brief flash of 'Middle English', James's poem is printed in black-letter type. The poet makes his intentions explicit in his signature: 'Sic officiosè a)rxai/zein conatus est', 'thus dutifully he attempted to archaize'. This fascinating work deserves to be quoted in full, and we have supplied, as far possible, a translation into Modern English: ${ }^{46}$

Certes, yt is a thinge right harde to done

Thee myckel Prayse, o doughtie KYNASTONE, I peyne me sore to done Thee grace, for here

I Thee alowth there no wight nys thy peere,

And who that saith it nat he is right nice,

I dare well wage, tho mote mine herte agrise,

In bytter stound all were my life etern,

Bote if I should thee prayse both late and yern.

There nas none wight couth wryte more thriftely

Ne eke more bet, ne eke more Clerkly,

There nyst none speken bet of Troilus,

Ne of dame Creseid ne of Pandarus,

For that thy boke beareth alder prize,

That I nat how vnneth thou couth devise,

To maken Chaucer so right wise and sage

Who couth all craft in werkes, take pilgrimage

\footnotetext{
${ }^{45}$ Oxford, Bodleian Library, MS James 34, f.1r. This manuscript contains the unique copy of James's 'edition of Ocleve', and nothing else. It is mentioned, along with a handful of other early modern references to Hoccleve, in Nicholas Perkins, Hoccleve's 'Regiment of Princes': Counsel and Constraint (Cambridge, 2001), 153n8. For more on Richard James, see Tom Beaumont James, 'James, Richard (bap. 1591, d. 1638)', Oxford Dictionary of National Biography (Oxford, 2004; online edn. Jan 2008).

${ }^{46}$ We have tried to follow James's language wherever possible, rather than imposing a more idiomatic translation. It is sometimes possible to find a clearer meaning for one of James's terms by turning to the definition supplied by Speght in his glossary to Chaucer's Works, rather than what is more familiar to us from the Middle English Dictionary; although not the only lexicographical resource for a reader of Middle English in the seventeenth century, Speght's glossary was certainly the most extensive and most readily available. See Pearsall, 'Thomas Speght', pp. 81-2.
} 
To Rome, and sothly there lerne Latine verse

In little throwe, so seemelyche to reherse.

With sythes of connyng thou hast mowen clean

Toforne thee great Reekes: that I but glean

Fro the great shefes of wytt, with boystous worde

In lewdness fro thilk wrytings that afforde

Swylke goodlyhede, tho stant I evyll apayd,

Whan men me iape and moughten me vpbrayd.

Withouten maugre, thou hast mowen the flower

Fulfilled of all Courtship and all honour,

Farced with pleasaunce and all goodlyhede

That deyntie is to see: Thee thus I reade,

Faire mought thee fall, who art the second Poet

From Brittons Homer nephew to Payne Roet.

It is a very difficult thing indeed, to praise you greatly, O noble Kynaston; I take great pains to show you favour, for here I extoll ${ }^{47}$ you: no man is your equal, and whoever does not say so is very foolish. I venture to say, though my heart might shudder with fear, that my life would forever ${ }^{48}$ be in a painful state unless I should praise you all day. There was no man that knew how to write more profitably, nor better, nor in a more scholarly manner; no one knows how to speak better of Troilus, nor of Lady Criseyde, nor of Pandarus. For this your book bears the chief ${ }^{49}$ prize, so much so that I scarcely know how you can arrange to make Chaucer (who is so very wise and sage, and who knows all the skills in composition) take a pilgrimage to Rome, and there in a short time learn true Latin verse, so beautiful to recite. With scythes of knowledge you have cleanly mown down before you great hayricks, so that I merely glean from the great sheaves of understanding (with halting ${ }^{50}$ language, in ignorance), from those writings that provide such virtue, although $^{51} \mathrm{I}$ am very disconsolate when men mock me and are able to upbraid me. Without blame, you have mown the flower that is filled with all courtliness and honour, beautified with pleasure and virtue that is delightful to look upon. This is my counsel to you: may fair things befall you, who are the second poet after Britain's Homer, the nephew of Payne Roet.

Unlike Evans's brief and scurrilously punning 'withouten Defalcation', James's effort is a much more sustained attempt at Chaucerian imitation. Although James does not

\footnotetext{
${ }^{47}$ For 'alowth' see also MED, sv. alouen, v. 1(a). The strange form 'alowth' seems rather third-person than first-person; could this possibly be a warped recollection of Speght, 'alose, commend' (sg. Ttt1v.). James's 'alowth' may also be incorrect borrowing from 'allow thee': 'I grant you here that no man is your equal'.

${ }^{48} \mathrm{We}$ have assumed that James intends the word eterne, an adjective in Middle English, to be understood as an adverb. The sense of these lines is rather obscure.

${ }^{49}$ alder in Middle English is the genitive form of al, 'all'; James seems to be following the slightly looser definition suggested by Speght: 'all alone, onely, cheefe' (sg. Ttt1r.).

${ }^{50}$ Speght, boystous, 'halting: also plaine, rude great' (sg. Ttt3).

${ }^{51}$ Note that the Middle English Dictionary does not attest any occurrence of the word though (conj.) with James's spelling, 'tho'. However, James's usage is supported by Speght's glossary, where tho is said to mean both 'those' and 'although' (sg. Uuu5). One possible meaning of these lines, perhaps preferable, is to take tho to mean "then" (MED, sv. tho, adv., 1.)
} 
directly cite any writings beyond Troilus and Criseyde itself, the poem demonstrates a remarkable familiarity with a host of works by Chaucer. James has perhaps also absorbed elements of Speght's brief excursus on Chaucer's language, as can be seen, for example, in his use of double negatives for emphasis ('There nyst none speken'). ${ }^{52}$ But James's 'Middle English' is often surprisingly accurate, and for a great deal of his phrasing it is possible to find a close parallel in Chaucer. It is difficult to say whether James is consciously weaving together a tissue of Chaucerian allusion, or turning to Speght's edition for ready-to-hand phrases or expressions, but taken as a whole his poem reveals a wide-ranging knowledge of Chaucer. Verbal parallels abound, of the Canterbury Tales in particular, ${ }^{53}$ and, as one would expect from a work attached to the Amorum Troili, James's promise to praise Kynaston 'both late and yern' (8) unmistakably recalls Troilus's emotional words to Pandarus in Book III of Troilus and Criseyde. ${ }^{54}$ Yet some of Chaucer's less famous works, such as the Romaunt of the Rose and the Legend of Good Women, also find striking echoes. ${ }^{55}$ Intriguingly, there are also hints of that piece of Chaucerian apocrypha so popular in post-Reformation England, The Plowman's Tale, which had appeared in every edition of the Tales since $1542 .{ }^{56}$ More loosely, some of James's phrasing seems also to echo La Belle Dame sans Mercy, which was printed by Speght as a work by Chaucer, but is now known to be by Richard Roos. ${ }^{57}$

The most extensive of James's borrowings from one of Chaucer's texts is also perhaps the most surprising, since, as with The Plowman's Tale and La Belle Dame sans Mercy, today we understand that this text's author was not, in fact, Chaucer. The Testament of Love by Thomas Usk (c.1354-1388), a prose treatise in imitation of Boethius's Consolation of Philosophy, has not survived in any medieval manuscript copies; it was printed, however, in William Thynne's 1532 edition of Chaucer's

\footnotetext{
${ }^{52}$ Speght on double negation: 'It is his manner likewise, imitating the Greekes, by two negatiues to cause a greater negation : as, I ne said none ill', sg. A4r.

${ }^{53}$ For echoes of The Canterbury Tales, compare 'mote mine herte agrise' (6) to 'that youre hertes might agryse' (CT, III 1649), but see House of Fame, 210; compare also 'pleasaunce [...] That deyntie is to see' (27-8) to 'pleasaunce / That it was deyntee for to seen' (CT, IV 1111-2); 'in little throwe' (18) to 'in a litel throwe' (CT, III 1815). There are some looser imitations or recollections of the Canterbury Tales that remain noteworthy: compare James's 'for here / I alowth there no wight nys thy peere' (2-3) to 'I allow thee [...] ther is noon that is heere / Of eloquence that shal be thy peere' (CT, V 676-8); for the opening line, 'Certes, yt is a thinge right harde to done', compare "“Certes," quod Prudence, "it is an hard thyng", (VII 1751). Although we have been unable to find a direct analogue in Chaucer for the full phrase 'tho stant I evyll apayd' (23), the phrase 'evyll apayd' is a common Chaucerian locution, see IV 1565, IV 2392, V 1282, V 2246, VII 707, etc.

${ }^{54}$ Compare James's 'In bytter stound all were my life etern, / Bote if I should thee prayse both late and yern' (7-8) to 'Achillies with his spere / Myn herte cleve, al were my lif eterne, / As I am mortal, if I late or yerne / Wolde it bewreye' (III 374-5). The collocation of 'late' and 'yerne', and the rhyme eterne : yerne occur only here in Chaucer, so James must have been echoing Troilus, but it is unclear whether this is intended to be understood as a direct allusion.

${ }^{55}$ For echoes of the Legend of Good Women, compare 'beareth alder prize' (13) to 'bereth our alder pris' ( $L G W$ Pr.F 298); 'farced with plesaunce' (27) to 'farced with plesaunce' ( $L G W 1373$, where the context is one of blame rather than praise); compare 'Fulfilled of al Courtship' (26) to 'Fulfilled of alle curtesie' (Romaunt of the Rose, 640).

${ }^{56}$ Compare 'I dare well wage' (6) to 'I dar wel wage', The Plowman's Tale, ed. Skeat, 1207. This is not a common phrase in Middle English, and note that Speght's spelling in his print is 'I dare well wage', fol. 91v. See also James's 'Faire mought thee fall' (29), which seems to be an inversion of the oft-repeated refrain that first appears at Plowman's Tale, 60: 'The falser, foul mote him befall!' ${ }^{57}$ James's phrase 'Withouten maugre' (25), appearing close to 'goodlyhede' (27) recalls 'Withouten maugre of your most goodlihede', La Belle Dame sans Mercy, 240, in Skeat, ed., Chaucerian and Other Pieces. 'Withouten maugre' does not occur elsewhere in Chaucer's writings.
} 
Works, gaining a foothold in the canon of Chaucer's writings until its authorship was correctly attributed to Usk in the nineteenth century. ${ }^{58}$ Speght follows this practice. For early-modern readers, therefore, Chaucer's oeuvre included this unusual prose piece. It was natural for these early editors to attribute the work to Chaucer; in it, the God of Love mentions the 'noble philosophical poete in Englissh' who has discussed love at length in his 'boke of Troilus'. ${ }^{59}$ James's imitation of the Testament of Love is of considerable interest not merely because it demonstrates how this text, little read today, was welcomed happily into the seventeenth-century understanding of Chaucer, but also because it constitutes a fascinating instance of early-modern versification of a Middle English prose work:

With sythes of connyng thou hast mowen clean

Toforne thee great Reekes: that I but glean

Fro the great shefes of wytt, with boystous worde

sithen al the grettest clerkes han had ynough to don, and (as who sayth) gadered up clene toforn hem, and with their sharpe sythes of conning al mowen, and mad therof grete rekes and noble, ful of al plentees, to fede me and many another.

(I. Pr. 97-101)

These three lines are the most sustained imitation of any passage of Middle English in James's poem, and taken alongside some other, looser echoes, it places a great deal of emphasis on this Chaucerian work not by Chaucer. ${ }^{60}$ James's mistaken reading of the Testament of Love as a work by Chaucer constitutes a major piece of evidence in the history of the early-modern reception of Chaucer as a writer of prose.

James seems to have had a strong grasp of archaic lexis. He must intend the verb 'iape' (24) in its Chaucerian rather than early-modern sense, and perhaps he is even parading his command of archaic language by using jape in a context where a double-entendre hovers in the background but must be dismissed. ${ }^{61}$ But James's grasp of Middle English syntax is less strong: sometimes, by transplanting seemingly genuine Chaucerian phrases from their original context without changing the syntax, he generates solecism. ${ }^{62}$ His metre, likewise, is unusual: as might be natural for a

\footnotetext{
${ }^{58}$ See Skeat, Chaucerian and Other Pieces, xviii-xxxi.

${ }^{59}$ Skeat, Chaucerian and Other Pieces, III, ch. 4, 249, 258-9.

${ }^{60}$ For other echoes of Usk's Testament, compare James's 'boystous worde' to 'rude wordes and boystous' (Testament, Pr. 7, 11-2); compare, more loosely, 'who couth all craft in werkes' (16) to 'the crafte of a werkeman is showed in the werk' (Testament, Pr. 48-9).

${ }^{61}$ In the early-modern period the primary senses of jape, 'to trick' or 'to mock', dropped out of use under the influence of its sexual meaning, 'to have carnal intercourse' (OED, s.v. jape, v.1-3). Speght actually makes explicit the consequences of misunderstanding this term in an amusing entry in his glossary to the Works, where the following definition jape is given: 'Iest, a word by abuse growen odious, and therefore by a certain curious gentlewoman scraped out in her Chaucer: whereupon her seruing man writeth thus: My mistres cannot be content, / To take a iest as Chaucer ment, / But vsing still a womans fashion / Allowes it in the last translation : / She cannot with a word dispence, / Although I know she loues the sence. / For such an vse the world hath got, / That words are sinnes, but deeds are not' (sg. Ttt6r).

${ }^{62}$ In the phrase 'stant I evyll apayd', the verb seems to be third-person in form, though is clearly meant to be first-person in meaning, although we have been unable to find a convincing source in Middle English from which this phrase is lifted.
} 
seventeenth-century poet, he writes in iambic pentameter, and seems to have grasped that Chaucer wrote in a similar five-stress pattern (although James often elides syllables that would have been pronounced in Middle English). In one instance, James possibly shows a vague awareness that the word-final $-e$ of some words in Chaucer could have a syllabic value: this is the word 'toforne' in the lines from Usk quoted above. Although toforen was indeed etymologically trisyllabic in Middle English, James is mistaken about the syllabic value of word-final $-e$ elsewhere, and this particular instance seems to have been a lucky strike. ${ }^{63}$ However, it is nevertheless interesting that James allows himself some metrical flexibility, and he perhaps recognised that Chaucer's English metre was governed by different rules than his own. He may be responding here to Speght's hint that Chaucer's lines are not as unequal as they seem - 'a skilfull Reader, that can scan them in their nature shall find it otherwise'. ${ }^{64}$ Both James and Speght may have known George Gascoigne's comments on Chaucer's metre; Gascoigne claimed that 'one that hath understanding' will be able to see the complex system underlying Chaucer's apparently defective lines. ${ }^{65}$

As the brief and perhaps somewhat obscure reference to 'Payne Roet' in the final line shows, James also engages closely with the idea of Chaucer the man as presented by Speght, from whose brief prefatory life of Chaucer this unusual detail is gleaned. But in this final couplet, where Chaucer becomes the foundational 'Homer' of English writing, James may be doing more than making passing reference to a digressive biographical detail. As Speght's genealogy of Chaucer makes clear, 'Payne Roet', or Sir Gilles de Roet, was the father of both Chaucer's wife and Katherine Swynford, who married John of Gaunt in a union that would lead in a few generations to the birth of Margaret Beaufort, mother of Henry Tudor. ${ }^{66}$ Such a reference would not have been lost on Kynaston, a staunch royalist who, as we noted earlier, authored a manuscript treatise against the antiquity of parliaments. James ends his remarkable 'Middle English' poem by placing Chaucer and - by implication, Kynaston - in the company of kings; this was a position that Kynaston, certainly, would very much enjoy. ${ }^{67}$

Francis James wrote little else, but it seems that his experiment with 'Chaucerian' English left him with a taste for this kind of writing, for the only other verse in English of his we have traced is another commendatory poem, this time set before the 1638 English translation of the second-century A.D. Alexandrian writer Achilles Tatius's Leucippe and Clitophon, one of the few surviving Ancient Greek prose romances. This was again published on the Oxford press, under the title The

\footnotetext{
${ }^{63}$ In Chaucer's English the contracted phrase thilke (the + ilce) would have a syllabic word-final $-e$ before a consonant. This is not the case for James's 'thilk' (22).

${ }^{64}$ Works, sg. A4r.

${ }^{65}$ See George Gascoigne, "Certayne notes of Instruction”, in Works, ed. John W. Cunliffe, 2 vols (Cambridge, 1907) 1.467.

${ }^{66}$ See Speght, sg. B4r. The connection is made yet more explicit in Speght's frontispiece, which shows Chaucer's portrait surrounded by this illustrious genealogy, descending all the way to 'Henry 7, Kinge of England' (f. 2r).

${ }^{67}$ It is remotely possible that the Bohemian exile Clemens (see above, n.24) had read and reacted to James's poem too. Both link Chaucer to Homer; both figure translation into Latin as a journey to Rome (albeit the journey in Clemens is Criseyde's not Chaucer's); and Clemens in the conclusion to his section on Chaucer uses 'nepos' in the sense 'descendant', as James appears to use 'nephew' here. This is cumulatively striking; but it must also be countered that there is little independent evidence that Clemens could read any sort of English with critical attention.
} 
Loves of Clitophon and Leucippe. The translator was Anthony Hodges, a chaplain at New College, which may explain the Francis James connection. James is the only one of the ten men contributing prefatory poems to this book to furnish two, one in Latin, and one in 'English', which proves to be another attempt at Chaucerianism, printed once again in black-letter, and explicitly aligning itself with James's earlier effort. ${ }^{68}$ As a poem in praise of Hodges's translation, James's work is rather odd, and is of particular interest to our investigation here because it devotes most of its space not to Hodges at all, but to a discussion, once again, of Chaucer and Kynaston's translation of Troilus and Criseyde. James opens his poem by paying homage to another Greek romance, this time the Athiopica of Heliodorus, a work of immense popularity following its rediscovery in the early sixteenth century. Since James is writing to commend Hodges as a translator of Greek prose, we might expect these opening lines to exalt one of the two translations of Heliodorus available in the seventeenth century, either that of Thomas Underdowne, published in 1569 (six editions to 1622), or, more likely, the more recent attempt by William Lisle - incidentally also a pioneering scholar of Old English - whose verse adaptation was published in 1631 and again in 1638. However, what we find instead is a brief anecdote concerning Heliodorus's supposed career, before James turns at length to discuss the writer of another lovestory set in the ancient world: Chaucer. If it seems strange for James to turn to Chaucer in the context of Ancient Greek romance, it is worth recalling that Shakespeare's (probably collaborative) Pericles (first printed in 1609; five quarto editions alone to 1635) derived its plot from the romance Apollonius of Tyre, as mediated through John Gower's Confessio Amantis; Pericles indeed features Gower as Chorus, who introduces the play with some slight touches of mock Middle English, and reappears at intervals thereafter. It is therefore possible that for more than one early-modern writer, Middle English literature was imaginatively associated with the exotic prose romances of the ancient world. In the full quotation of James's poem below, we have reproduced the explanatory footnotes that appear alongside it:

Friend, I thy boke compare with swilk of yore, With mighty deeds of worthy Heliodore,

Proud Antioch's Prelate: whan he wrote his werk And was forthy depos'd: ${ }^{69}$ Thilk Asian Clerk Hight Bishop too, yet lives, whose buxom pen Maugre all envy made him man of men.

As whilom for the lore of Englond

\footnotetext{
${ }^{68}$ Achilles Tatius, The Loves of Clitophon and Leucippe. A Most Elegant History, written in Greeke by Achilles Tatius, and now Englished (Oxford, 1638). For the translator and the book see Wood, Fasti, vol. 1, col. 501, and Madan, Oxford Books, I, pp. 203-4. Wood commented that there were two impressions of the book: one with and one without the commendatory verse, which shows once again how such books were put together. Madan was incorrect to claim this as the first translation into English of Achilles Tatius, but William Burton's 1597 translation is exceptionally rare, there being only one copy listed in ETSC. Both James and Hodges likewise seem unaware of the earlier effort. James's Latin poem is entirely classical in reference.

${ }^{69}$ The tradition that Heliodorus was a bishop stems from Socrates Scholasticus, Historia Ecclesiastica, 5.22, where however he is said to have been the Bishop of Tricca. The tradition that he was deposed from his bishopric for refusing to disown this youthful work comes from the fourteenth-century Byzantine historian Nicephoras Callistus. The two anecdotes were thereafter frequently combined in testimonials, e.g. that set before Lisle's verse translation of Achilles Tatius (London, 1638, sg. A2r, reproducing a testimonial from Martin Crusius).
} 
Gaufrid an orpyd knight toke upon hond

To wryten thilk throwe; for all ages after

Of Troyl hight Pryam's son and a Calchas daughter;

'The double sorows of those wights to tellen,

'Froe woe to wele how their aventures fellen.

Clepend on Muse, to help for to endite

His balefull verse that weepen as he write.

Forthy a ${ }^{\mathrm{b}}$ Muses sonne in gret nobles,

That can of Knighthode chivalrie and prowes

The lore; whos goodship algates did deserve

The studdie of thilk Goddes ' hight Minerve,

'Payne Roët's Nephew so did understond,

As shope him to the lenguage of Rome's lond:

So I full lewd and (though I not the quill

Of doughtie knight, ne eke of ${ }^{\mathrm{e}}$ Astrophill)

In tiny connyng which me underfongeth,

Do thee al preyse as it of right belongeth,

And sikerlie endevor to avance

Thy goodship, and the Muses chevisance:

Yf yn some oder lenguage clerks that conne

Will put in verse Leucip and Clitophon

a Cressida. b Sir Francis Kynaston. c Minervae Musceum. d Chaucer. e Sir

Philip Sydney.

James's second attempt to imitate Middle English is quite different in style to the effort he presented for Kynaston's Amorum Troili. Whereas his earlier poem was largely an interweaving of direct borrowings from works attributed to Chaucer by Speght, the second poem does not borrow heavily from Chaucer's actual writings with the exception of the prominent paraphrase of Troilus and Criseyde, looked at more closely below. In this work, James's 'Middle English' is confined mostly to archaic spellings and some Middle English lexis. It may reveal James's interest in Middle English literature beyond Chaucer, although the correspondences are much less close than in his previous piece. Whereas Chaucer never uses the word orped ('valiant'), James's phrase 'orpyd knight' (8) does appear twice in Gower, and the cooccurrence of the rhyme-words lond and hond in the second of these instances may suggest that James is vaguely recalling a passage from the Confessio Amantis. ${ }^{70}$ The word 'orped' seems to have belonged primarily to the lexis of Middle English romance, and in style and tone this poem by James perhaps reveals the influence of the English romances as channeled through Gower and, in particular, Spenser's Faerie Queene. Although orped is not to be found anywhere in Spenser, James's 'doughtie knight' (22) was one of Spenser's favourite formulae, and several of the words James uses seem to be intended in their Spenserian rather than genuinely medieval sense. ${ }^{71}$ Although James's mention of the 'doughtie knight' does not come

\footnotetext{
70 'He made hym kniht and yaf him lond, / Which afterward was of his hond / An orped kniht in many a stede' (III.2413-5). All quotations from John Gower, Confessio Amantis, in Works of John Gower, 4 vols. ed. G. C. Macaulay. For the other occurrence of 'orped kniht', see I.2590.

${ }^{71}$ For occurrences of 'doughtie knight' in Spenser, see The Faerie Qveene, ed. A. C. Hamilton, Hiroshi Yamashita, and Toshiyuki Suzuki (Harlow: Longman, 2001) II.v.26.4, III.iii.24.1, IV.iv.3.2, IV.iv.42.9,
} 
with an explanatory footnote, the fact that it appears alongside 'Astrophill' - glossed in the footnotes as 'Sir Philip Sydney', the dedicatee of Spenser's Shepherds' Calendar - suggests that the formula may even be referring to Spenser himself, highlighting Chaucer's position as the originary source of a continuous English poetic tradition.

Indeed, these Spenserian echoes raise some perplexing questions. It is difficult to judge the extent to which James is deliberately evoking a Spenserian atmosphere here; any archaising English poet might naturally turn to Spenser as a model, and the 1579 Shepherds' Calendar was of course printed in black-letter type, perhaps suggesting a way of presenting archaic language to later printers. Yet it may also be the case that when James is composing an 'original' poem in imitated Middle English, rather than a work woven from snippets of Chaucerian quotation, that he lapses into the more familiar diction of Spenserian archaism. The fact that some similar archaisms are used by those few early seventeenth-century imitators of Spenser might suggest that the supposedly Middle English lexis transmitted via the Faerie Queene and Shepherds' Calendar retained some currency in the seventeenth century, and while not in common usage, was relatively transparent. ${ }^{72}$ These issues are brought into focus by James's word 'quill' (21). Do we understand this in the familiar sense 'pen', chiming with the 'buxom pen' of line 5 and the idea of writing and writtenness in the quotation from Troilus, or in the Spenserian sense 'a shepherd's pipe' (evoking the imagined realm of English pastoral) ${ }^{73}$ While the extent and intensity of James's archaism clearly distinguishes him from Spenser and the Spenserians, this poem may well have evoked the spectre of Spenser for James's readers. For a seventeenthcentury thinker interested in the history of English poetry, there were in effect two competing visions of Middle English literature: the 'authentic' writings of Chaucer as presented in the early prints, and Spenser's artificial archaism, evoking pastoral

etc. For James's 'underfongeth', see OED, s.v. underfong (v.5), 'To seduce, entrap, overcome' - a meaning that first appears in Spenser. Likewise, 'chevisaunce' (26), is clearly intended in the sense given in $O E D$, s.v. chevisance (n.8b), 'Misused by Spenser and others after him [...]Enterprise, performance; chivalrous enterprise or achievement'. Other possible Spenserianisms include the suppression of the article in the phrase 'doughtie knight', characterised by E. A. Abbot as a deliberate archaism in the Elizabethan period and associated with Spenser; see E. A. Abbott, A Shakespearian Grammar: An Attempt to Illustrate Some of the Differences Between Elizabethan and Modern Usage (London: Macmillan, 1884), §82, 'A and The omitted in archaic poetry'. A final, more general Spenserianism is 'thilk' $(3,9)$. Although a genuine Middle English word, it was not consistent with Chaucer's dialect, and occurs only in his imitation of Northern speech in the Reeve's Tale; yet thilk does occur regularly in Spenser's Shepherds' Calendar: see Charles Grosvenor Osgood (ed.), A Concordance to the Poems of Edmund Spenser (Washington, D.C.: Carnegie Institute, 1915), s.v. thilk. Note, however, that James's 'swilk' (1) does not occur in Spenser. In modern editions of Chaucer, we find that Chaucer uses this word once in imitation of Northern dialect in the Reeve's Tale (I.4171), generally preferring in that narrative to use an alternative northernism, slyk, from ON slikir (eg, 'Slyk as he fyndes, or taa slyk as he brynges', I.4130). But note that Speght in his edition of the Reeve's Tale tends to alter Chaucer's slyk to swilk: 'Swilk as he findes, or swilk as he brings' (f. 15v).

${ }^{72}$ For Spenser's imitators in this period, see Paul J. Klemp, 'Imitations and Adaptations, Renaissance (1579-1660)', in A. C. Hamilton (ed.), The Spenser Encyclopedia (Toronto and Buffalo: University of Toronto Press, 1990), pp. 395-6. It is beyond the bounds of this study to attempt an analysis of the archaic lexis of the seventeenth-century Spenser tradition, but it is worth observing that the two major imitators of Spenser in the period, William Browne (especially in The Shepheard's Pipe, 1614) and Phineas Fletcher, also make use of archaic lexis. Although a great deal of this can be traced back to Chaucer, some of it is specifically Spenserian. Some of this diction was not alien to seventeenthcentury readers.

${ }^{73}$ See $O E D$, s.v., quill (n.1c). This usage is frequent in the pastoral verse of Browne and Fletcher. 
rusticity. In this poem, James bears the imprint of the latter; but it is always possible that James was writing for an audience (Hodges and his friends) who were not as familiar with the obscurities of Middle English as Kynaston and James's fellow New Collegians.

James's paraphrase of the opening lines of Troilus and Criseyde merits special attention. Having introduced Heliodorus, James suggests that Chaucer, too, has been immortalised through his writing, by making available the story of Troilus and Criseyde for 'the lore of England' (7). He then offers a condensed, four-line version of Chaucer's opening stanza:

'The double sorows of those wights to tellen,

'Froe woe to wele how their aventures fellen.

Clepend on Muse, to help for to endite

His balefull verse that weepen as he write.

$(11-4)$

The double sorwe of Troilus to tellen, That was the kyng Priamus sone of Troye, In lovynge, how his aventures fellen Fro wo to wele, and after out of joie, My purpos is, er that I parte fro ye. Thesiphone, thow help me for t'endite This woful vers, that wepen as I write.

$$
\text { (I.1-7) }
$$

James's punctuation suggests that we should understand the first two lines as direct quotation, before the second couplet lapses into a more free imitation. Although James substantially changes the meaning of all the lines, the first couplet is indeed more closely keyed to Chaucer's text than the second. James's first two lines are a collage of close but not exact quotation, altering the meaning of the first line to refer to both Troilus and Criseyde, before weaving together quotations of two half-lines from elsewhere in Chaucer's opening stanza. James's second couplet intervenes a little more in the text. He excises Chaucer's alarming reference to the Fury Thesiphone (Tisiphone) by replacing her with a simple 'Muse'. The verb in the phrase 'Clepend on Muse' is genuine Middle English: although the participial form -end of clepend does not appear in Chaucer, it may have been familiar to James from his reading of Gower. In shifting from quotation to indirect speech in this second couplet, James effects a change in both person and tense. While Chaucer's 'I write' is firstperson singular and present tense, James's 'he write' can be understood most clearly as the variant preterite form, writ - 'he wrote'. But if this is so, James has damaged the rhyme: the short stem vowel of writ does not rhyme with the long $i$ (or diphthong) of endite. James has either made an understandable error in his understanding of Middle English syntax or phonology, or he is happy to use a false rhyme to create the impression of an imagined archaic pronunciation. James seems also to have taken pains to present Chaucer's metre as regular iambic pentameter; by selecting and tweaking the language of Chaucer's opening stanza, James removes potential difficulties for the early-modern reader, such as the tri-syllabic pronunciation of 
'Troilus' or the pronunciation of 'aventures' as four syllables. ${ }^{74}$ But James is not trying to modernise Chaucer, and when he introduces words to adjust the metre, he is happy for these to be archaic - as in 'wights' (11). It is interesting to compare James's activity here to what Dryden would go on to do to Chaucer's metre in his Fables Ancient and Modern (1700). In his preface to this work, Dryden specifically refuted Speght by arguing that Chaucer's verse contained metrical imperfections that 'no Pronunciation can make otherwise'. ${ }^{75}$ Now, although James is in fact regularising Chaucer's metre in these lines, he is not modernising his language: he generates tensyllable lines by making use of Chaucerian language or by rearranging fragments of genuine Chaucerian quotation. Taken alongside James's perhaps fortuitous use of the tri-syllabic 'toforne' in his earlier poem for Kynaston, these lines perhaps suggest that James at least recognised that Chaucer's verse was supposed be iambic pentameter, long before Dryden would rewrite it in this metre because he believed it to be simply defective. James's alteration of 'woeful' to 'baleful' may constitute a kind of archaic 'hypercorrection', preferring a less commonly used word over the genuinely Chaucerian woeful. Although we are not able to assess the relative frequency of woeful and baleful in seventeenth-century English, 'hypercorrection' might also help explain James's inclusion of the archaic word 'wights', not original to Chaucer.

If James does a violence to Chaucer's text by making the terrible Thesiphone a mere 'Muse', in this way he heaps yet greater praise upon Kynaston; Kynaston is a 'Muses sonne' (15), and by highlighting Chaucer's relationship with the Muses, James brings these two poets into closer association. Indeed, in this poem James reveals his continued fascination with Kynaston as much as Chaucer. His oblique reference to Kynaston's goodship meriting 'The studie of thilk Goddes hight Minerve' (18) is rendered explicit in his footnote: James means Kynaston's Muscum Minervae, his academy for the gentry. ${ }^{76}$ Emphasising once again Chaucer's genealogical link to the Tudor monarchy as 'Payne Roët's Nephew' (19), James praises Kynaston by emphasising his closeness to his literary predecessor. As knights, they occupy the same social category: Chaucer is an 'orpyd knight' (like, perhaps, the 'doughtie knight' Spenser), while Sir Francis Kynaston is said to be expert in 'Knighthode' (16). Indeed, James praises Kynaston almost to the exclusion of the actual addressee of this commendatory poem, Hodges. James's final lines express his hope that learned scholars - 'clerkes that conne' (27) - will versify Leucippe and Clitophon in 'some oder lenguage' (27); the implication of these lines seems to be that James desires Hodges's English prose itself to be transformed into Latin verse, like Kynaston's Amorum Troili. This is very faint praise for Hodges indeed; perhaps, having already submitted one conventional Latin commendatory poem filled with classical reference, James now felt free to return to a favourite subject: Kynaston's Chaucer. But the very fact that James might choose to return to his own cod Middle English in a commendatory poem for an English prose translation of a second-century Greek

\footnotetext{
${ }^{74}$ Note, however, that proper names were often subjected to a particular metrical violence in the earlymodern period: see James's own monosyllabic 'Troyl' (10) for Troilus.

75 John Dryden, Preface to the Fables Ancient and Modern, 347, in James Kinsley, ed., The Poems of John Dryden, 4 vol. (Oxford, 1958).

${ }^{76}$ A reference to Kynaston's academy in the context of his translation of Troilus and Criseyde seems strange; the institution's constitutions, published in 1636, do not explicitly list the study of medieval English literature amongst the subjects to be explored there, unless the 'Knowledge of Antiquities', to be taught by Kynaston himself in the guise of 'Regent' would include some investigation of Middle English poetry. See The Constitutions of the Muscum Minervae (London: Thomas Spencer, 1636), sg. A1v.
} 
romance is testament to the importance of Kynaston's work, and demonstrates that James clearly expected the community of Oxford scholars who share the opening pages of Hodges's Leucippe and Clitophon to be familiar not only with Kynaston's publications and pedagogical activities in London, but also to have a reasonable grasp of some archaic Middle English vocabulary.

These dedicatory verses and James's second archaizing poem point to an enthusiasm for Chaucer among a group of New College fellows in the early seventeenth century. This enthusiasm does not seem to be matched by the other commendatory poems in Kynaston's book. These collegians may have been a group of scholars with a particularly close personal connection to Kynaston, or they may have independently pursued this unusual interest. While many of the fifteen contributors of celebratory verses find themselves trapped in an awkward doubleness - trying to exonerate Chaucer of the charge of rusticity but then complimenting Kynaston for civilizing him - the verses studied closely here demonstrate a deeper affinity with Kynaston's project and thus a greater sensitivity to the literary worth of Chaucer. But, that said, these three New College poems which engage directly with Chaucer carry their own problems: how can they praise Kynaston for throwing open Chaucer's Middle English when their own engagement with Chaucer's writing seems to preclude the need for a Neo-Latin translation? It is possible that this is a selfconscious irony at the expense of the translator: a learned joke between Chaucerian amateurs. This in turn may suggest that there is sometimes more to such commendatory verse than is often recognized. The scatological, and so, arguably, indecorous performance of Evans, although ultimately held in check by its genre, challenges the bounds of conventional praise: context and content are in appreciable tension. At any rate, Kynaston's work, its Oxford connection, and the evidence for a cluster of enthusiasts at New College all serve to offer a new window onto the academic readership of Chaucer in the early seventeenth century. Kynaston's Troilus is an important record of a moment in English literary history when language change was rendering Chaucer's work ever more remote even as the idea of his originary status remained strong; through a strange paradox, Chaucer's English could be more intelligible to the English when rendered in a language other than English. As Reade has it, in his fictive address to Chaucer, Kynaston's 'Latin stile / Hath Englisht thee'. 